\title{
Photogeomorphological studies of Oxford stone - a review
}

\author{
Mary J. Thornbush \\ School of Geography, Earth and Environmental Sciences, University of Birmingham, Birmingham, United Kingdom, \\ m.thornbush@bham.ac.uk
}

\begin{abstract}
This paper surveys work in geomorphology that incorporates photography to study landforms and landscape change. Since this is already a large area of study, the city centre of Oxford, UK is adopted as a case study for focus. The paper reviews broader literature pertaining to 'photogeomorphology' since the 1960s and delves into contemporary publications for Oxford geomorphology. Developments in the general field do not embrace close-range ground-based photography, favouring aerial photography and remote sensing. The author postulates that, as evident in the Oxford studies, that the subdiscipline should be less fixated on landscape-scale approaches and also employ close-up ground-based photography and rephotography in the assessment of landforms and landscape change. This broader scale of application could benefit the study of stone soiling and decay (weathering) studies as smaller forms may be overlooked.
\end{abstract}

Key words: photogeomorphology, historical photographs, rephotography, photography scale, Oxford

\section{Introduction}

The use of photographs in geomorphology is not a new approach. Indeed, photogeomorphology appeared in the 1960s in combination with photogeology used in petroleum prospecting (e.g., Kelly 1961). This petroleum exploration application of photogeomorphology occurred in tangent with photointerpretation in geology, for instance by Tator (1960) in the Manual of photographic interpretation published by the American Society of Photogrammetry. This subdiscipline appears with publications examining aerial photography in order to examine landforms as part of a photogeomorphology. In 1968, for instance, UNESCO published the proceedings of the Toulouse conference, which addressed the use of Aerial surveys in integrated studies of natural resources. This volume included photogeomorphology for landform studies based on aerial photographs (Miller 1968); it also contained other relevant studies on soil and vegetation as well as photointerpretation based on aerial mosaics. Photointerpretation of landforms and landscapes continued into the 1970s (e.g., Mollard 1973) and 1980s (e.g., Mollard, Janes 1984). For instance, geomorphologists employed aerial photography to discern fluvial patterns and to classify them (e.g., Kellerhals et al. 1976). This was before the advent of GIS taking over the domain of land-use classification, an area within physical geography that has flourished more recently.
Photogeomorphology was a remote sensing approach still mainly used for mapping in petroleum exploration in the 1980s (e.g., Talukdar 1980). The use of aerial photographs to aid mapping continued into the late 1980s, with soil mappers developing the method to include photopedology in the study of alluvial plains (Niyogi 1988); and 'photogeomorphic' studies were conducted of coastal landforms (Lind 1974), deserts (Geological Survey of India 1982), chalk cliffs (Birch 1990), deltas (Agarwal, Mitra 1991), and lakes (Erol 1999). In 1992, a book was published (still with the support of petroleum geologists) that specifically addressed Photogeology and photogeomorphology (Foster, Beaumont 1992). The volume contains papers that still apply the method to petroleum exploration, but also comprises geological interpretation. Most recently, Rivard (2011) published a book on Satellite geology and photogeomorphology. Moreover, infrared kite aerial photography (KAP) was field-tested at the Cheyenne Bottoms Preserve of The Nature Conservancy in central Kansas, USA by Aber et al. (2009) in order to obtain large-scale imagery. Even though photogrammetry has been developed, and has its own journals, for instance ISPRS Journal of Photogrammetry and Remote Sensing (volumes available online since 1989), photogeomorphology has remained as a relatively undeveloped branch of geomorphology that appears scattered throughout journals as a geomorphological technique applied within landscape studies and more broadly in the discipline. 
Aerial photographs remain pivotal to this subdiscipline; however, other approaches should be recognised.

This paper contributes to the development of photogeomorphology as a photointerpretation approach to examine landforms in physical geography from ground-level. The central aim is to make a contribution to landscape-change analysis using photogeomorphology that is ground-based rather than from the air (taken in flight or from a satellite), which is better suited to GIS. Hall $(2001,2007)$ referred to this ground-based photographic monitoring as 'photomonitoring'. It is arguable that such an approach still involves remote sensing, since no contact is made with the object, although inspection is from the ground. This is a completely nondestructive approach that can be employed to study tangible heritage (material culture) with the idea of cultural heritage conservation of the built environment in mind. More specifically, weathering studies of historical buildings for central Oxford, UK will be portrayed as exemplar of this type of subdisciplinary approach. Several studies are conveyed and examined for their united contribution to the development of an urban photogeomorphology, as part of an applied geomorphology (Fig. 1). Photographic studies have also been incorporated into contemporary considerations of environmental geomorphology and archaeogeomorphology (Thornbush 2012a). The city centre of Oxford, UK is the selected study area because of its recent proliferation of photogeomorphological studies, particularly since 2004 .

\section{Close-range ground-based methods}

Although photographs have been captured for the depiction of information, they are rarely appreciated as quantitative tools. Geographers often employ slides and photographs into their lectures for demonstration (e.g., McKendrick, Bowden 1999, 2000), as of landforms and

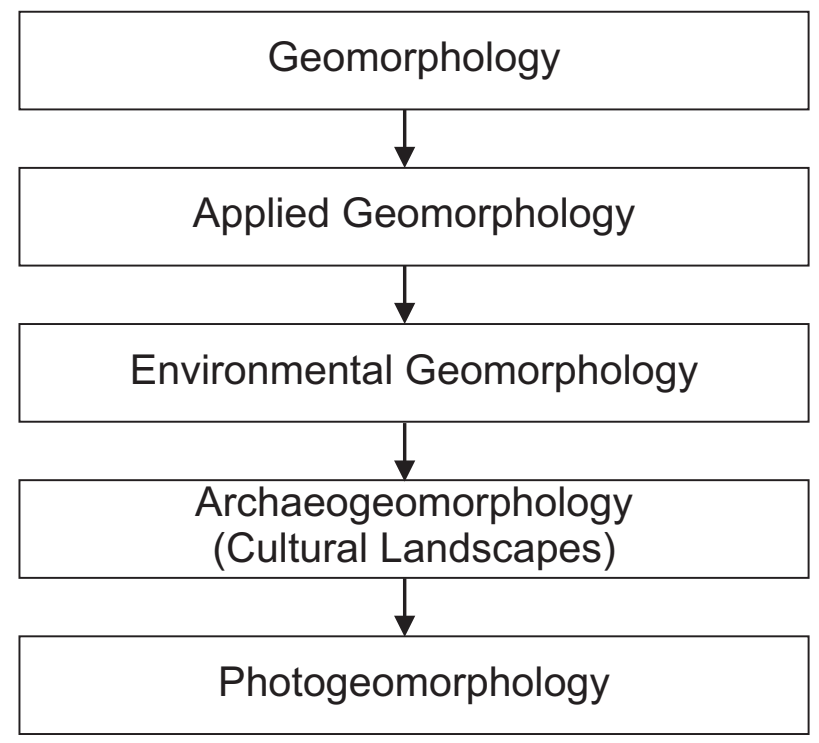

Fig. 1. Emplacement of photogeomorphology within geomorphology for Oxford studies landscapes by geomorphologists. Photographs are also used as part of fieldwork by physical as well as human geographers (e.g., Sidaway 2002). Although many examples exist where photographs were used qualitatively in a pictorial sense (Swallow et al. 2004), it is a rarity for studies to incorporate photo-based quantification. Nevertheless, Mottershead et al. (2003) executed a laboratory study that had some photographic input, as the authors attempted to capture visual evidence of etch features on polished marble samples through close-range photography deployed at a range of lighting angles. They found the technique to work only where the angle of incident light was equal to the angle of reflectance. Here, the authors make reference to a study by Inkpen et al. (2001), whereby scale was identified as a relevant consideration in the identification and mapping of decay features evident on Oxford stone. In a later study, Inkpen et al. (2008) used an integrated database and GIS approach in order to record and monitor stone degradation in Oxford.

Thornbush, Viles $(2004 \mathrm{a}, \mathrm{b})$ published a new method for the laboratory-based measurement of the close-up weathering of limestone that was derived from digital photography. Under controlled conditions (in the laboratory), it was possible to adjust indoor lighting so as to avoid the casting of shadows across the surface of relatively flat stone sensors from an exposure field study. The study was a part of the Environmental Monitoring of the Integrated Transport Strategies (EMITS) project, and the sensors had been exposed at roadside locations in the Oxford city centre. The authors were interested in colouration changes associated with outdoor exposure in a polluted environment, as well as soiling patterns emerging from this exposure. In these two studies, they established the IDIP method as a quantitative photographic technique of integrated digital photography and image processing that is simple to use and inexpensive (compared with photogrammetric approaches) to quantify surface change. The use of this method was extended outdoors with the development of the O-IDIP method (Fig. 2), which allowed for lighting calibration based on use of a spectrophotometer (Thornbush 2008a). A case study was executed, for instance,where the outdoor method was employed at the Ashmolean Museum (Thornbush 2010a). This work was

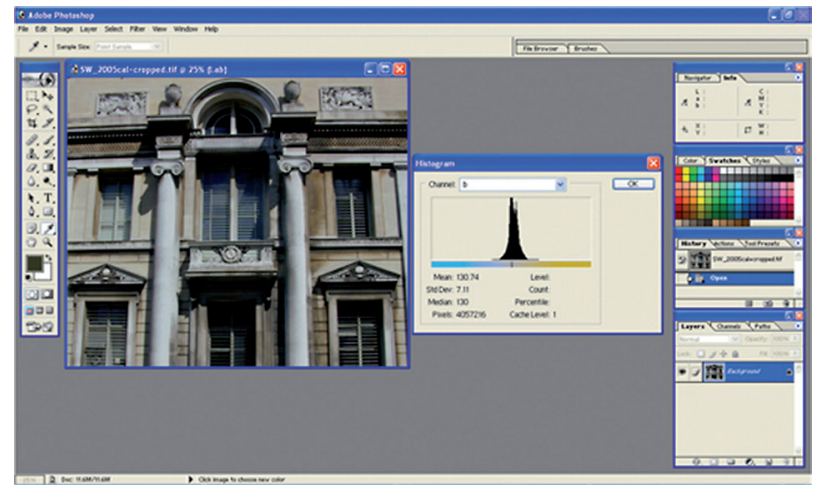

Fig. 2. Blue-yellow spectrum at the SW elevation of the Ashmolean Museum 
influenced by the doctoral thesis by Searle (2001), where Bath-stone buildings were investigated using a greyscale for the depiction of soiling (at the building-scale).

In addition to the IDIP method and its outdoor application, the O-IDIP method, Thornbush, Viles (2007a) devised the DMAP approach to assess the soiling of walls and their decay features. This decay mapping technique was executed in Adobe Photoshop (hence, the name decay mapping in Adobe Photoshop), where closed forms could be identified and areally quantified close-up using the software. Such a close-up approach was previously advocated by Chandler (1999) for geomorphological research. More specifically, a selection of area within decay forms (such as blisters) was possible in order to compare any expansion of these forms in cross-temporal photographic surveys (Fig. 3). The approach was advocated for longer monitoring surveys, spanning over 5 years. This adopted approach of rephotography has been used by many geomorphologists to track cross-temporal landscape change (e.g., Butler 1994). At the Grand Canyon (USA), for instance, Webb (1996) conveyed a classic rephotographic study of landscape change between 1889 and 1890. Cerney (2010) reviewed the use of repeat photography (rephotography) to decipher geomorphic patterns and processes in the past 40 years. Although geomorphologists have employed photography at the landscape scale in order to assess landscape change, few have examined its potential for the detection (and quantification) of closeup change, as of landforms and parts of landscapes rather than entire landscapes.

Some work by Thornbush, Viles (2008) approached landscape change of historical buildings from an integrated qualitative-quantitative perspective. Blister expansion was measured using an early form of the O-IDIP and the extent of this feature was assessed at the boundary wall of Worcester College (Fig. 4). More recently, Thornbush (2010b) performed a rephotography of a selection of buildings that had been photographed prior to the restorative works by the Oxford Historic Buildings Fund between 1957 and 1974, as conveyed by Oakeshott (1975). This provided a pictorial before-versus-after comparison

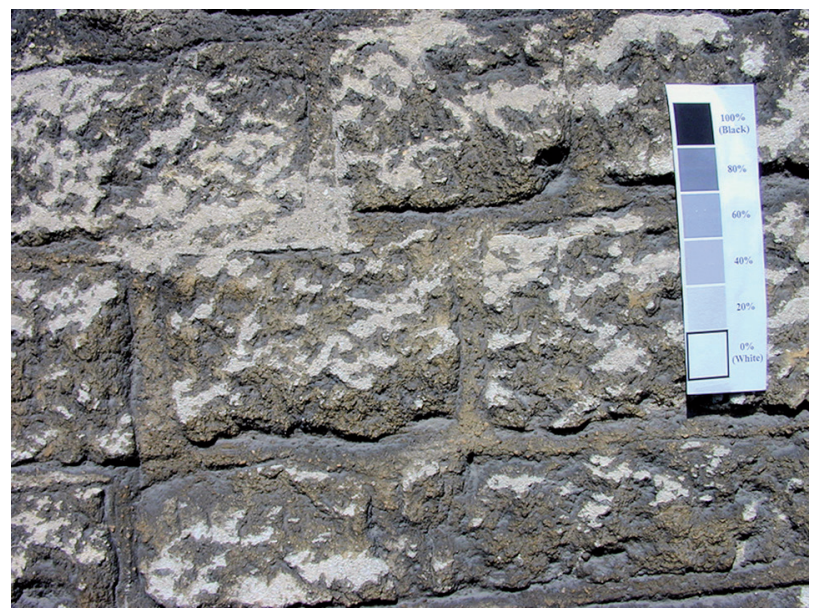

Fig. 3. Greyscale used for lightness calibration of Oxford studies of walls

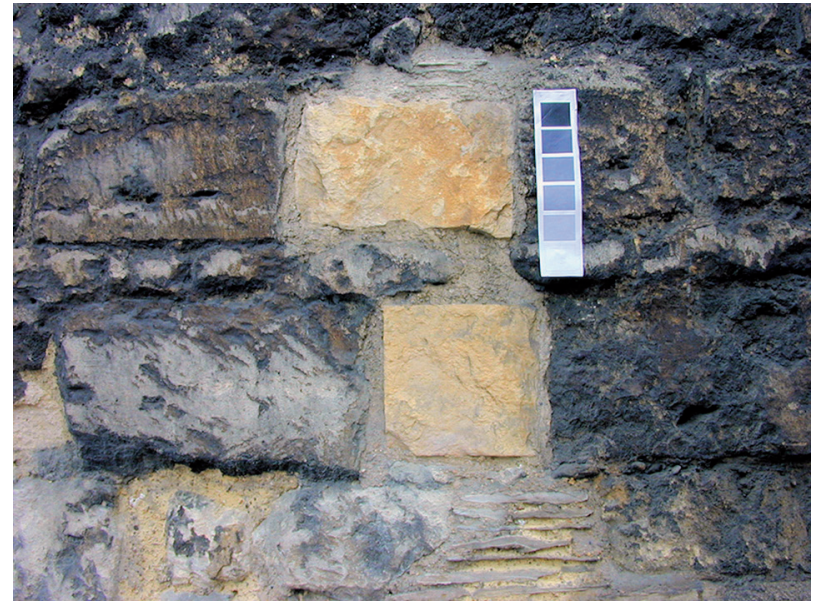

Fig. 4. Greyscale used for lightness calibration of the DMAP approach

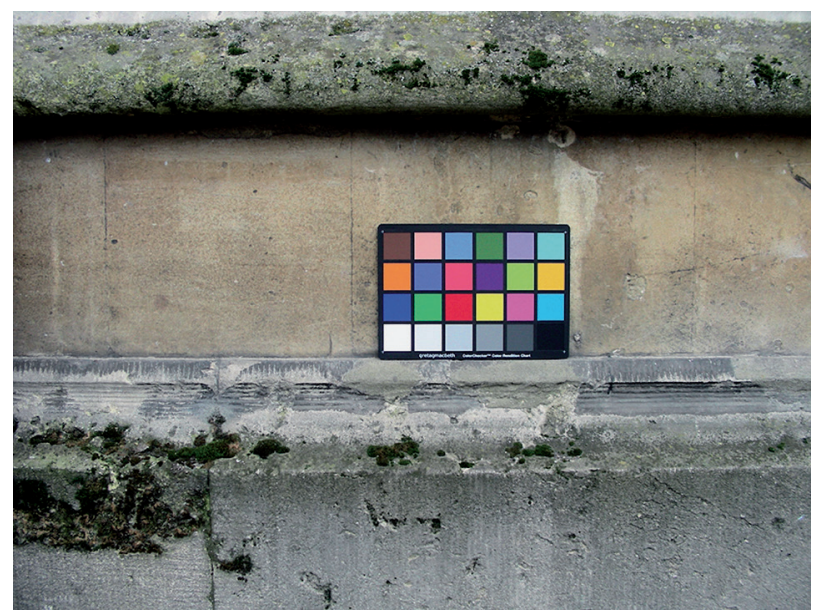

Fig. 5. Colorchecker used for chromatic calibration in an Oxford study of algal greening

of buildings included in his book Oxford stone restored. Most recently, a colorchecker (Fig. 5) was captured in photographs for chromatic calibration of images (e.g., Thornbush, in press). As part of a rephotographic approach, the use of photoarchives is much advocated, as in a study of the impact of traffic on the appearance of Magdalen College from its High-Street frontage (Thornbush, Viles 2005). Photoarchives have been examined more recently in cross-temporal landscape studies at Trinity (Fig. 6) and Pembroke Colleges (Thornbush 2012b). This latter research article also includes a detailed survey of literature pertaining to photography and rephotography.

\section{Contributions of Oxford studies}

The photogeomorphological work conducted in central Oxford, has been mostly quantitative in scope, as indicated by the methods developed to measure the soiling and decay of limestone at various scales. Novel techniques have been devised for the photographic study of limestone buildings. These methods have been predominantly outdoor-based, requiring field-portable equipment 


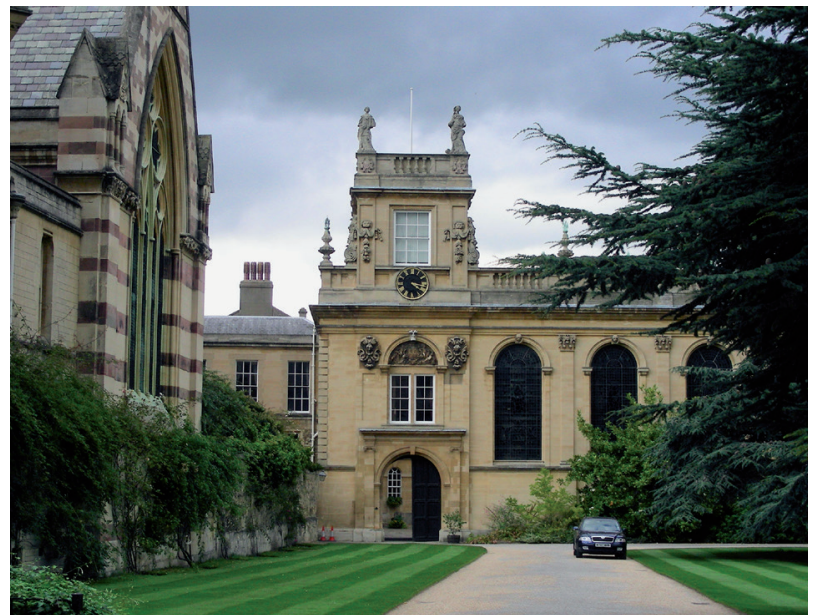

Fig. 6. Trinity College incorporated into various Oxford rephotographic studies

that is possible with the application of a (digital) camera. Moreover, in the context of historical-building research (heritage science), it is necessary that all methods (and instruments) remain nondestructive. In order to retain the integrity of this resource of cultural stone, surrogate samples have been claimed, as for instance through the use of stone sensors exposed for years in the urban environment in order to assess soiling and decay under these circumstances without consuming (or ultimately depleting) the resource. These sensors were examined for different purposes, including for SEM (scanning electron microscopy) analysis of close-up effects (Thornbush, Viles 2006). In addition to sensors, discarded stone has also been employed in some of these studies (Fig. 7), as from Somerville College (Thornbush, Viles 2007b).

Some of the more qualitative research has incorporated photoarchival materials, including historical photographs. Viles (1993, 1994), for instance, published a case study based at Trinity College on limestone blistering, and justified the use of archival photographs (and photographic sequences through time) in order to study the history of building stone decay. Such historical photographs were accessed at Oxford colleges comprising photoarchives and also included other photographic collections. Among these photographic collections at Oxford-college archives, there have been some postcards that were derived from photographs housed in these collections. Thornbush (2008b), for instance, accessed discarded postcards as representations of historical photographs in order to establish a temporal record of landscape change (environmental change) in central Oxford. Some of these photographic images can also be accessed online, through digitalised databases of historical photographs.

So far, photographs have been deployed for various purposes in central Oxford. For measurement of soiling (with the use of stone sensors as well as across various surveys of walls, including at the Ashmolean Museum). As well as for studies of limestone decay, such as of surveyed walls, as well as more specifically at the boundary wall of Worcester College, and most recently with work

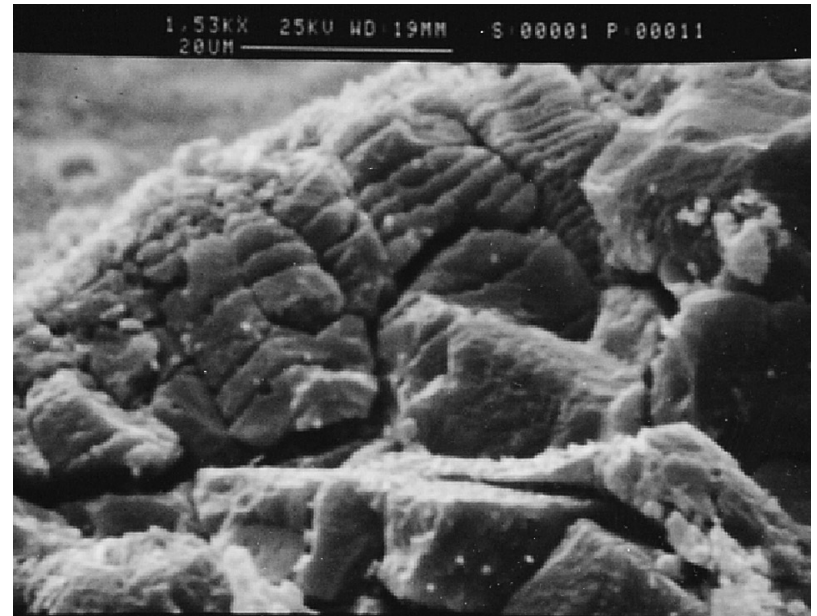

Fig. 7. SEM image of etched sample of discarded stone

in progress on biological colonisation, as by algae (Thornbush in press). Their contribution has been varied, from case studies of specific buildings to field and laboratory experiments. Their scale has also varied, from the microscale (SEM) to the macroscale (buildings) rather than more modern landscape scales accessed via aerial photography or satellite imagery.

\section{Conclusion}

The use of ground-based photography should be considered as part of modern photogeomorphology. Traditional views were to deploy aerial photographs for petroleum exploration and geological photointerpretation. Today, there are many examples of the use of photography to aid geomorphology, either in the classroom (for introductory geomorphology courses) or as part of fieldwork to portray the study area. Recent studies by geomorphologists also convey the use of close-range photography for such pictorial depictions, but also more quantitative approaches using simple digital (re)photography. The examples derived from Oxford studies are representative of a photogeomorphology that is land-based, close-up, and used to measure landform (to landscape) change in weathering studies of the built environment (historical buildings and structures). Such works have employed photography and rephotography to track landscape change in urban settings, but can also be extended to other settings and incorporated at various scales (from SEM to sensor to small sections of buildings to entire walls and whole buildings as well as spanning landscapes). They can be qualitative (pictorial) in scope or quantitative used to measure landscape change. Such a simple, economical, and nondestructive methodology can make growing contributions to the field of geomorphology, either by way of applied geomorphology (as in the current paper), or directly through photogeomorphology as its own geomorphology subdiscipline. Finally, photogeomorphology has much potential to be developed as a quantification tool, particularly in field ge- 
omorphology, where portable instrumentation is required to capture processes and landforms at various scales.

\section{References}

Aber J.S., Aber S.W., Buster L., Jensen W.E., Sleezer R.L., 2009. Challenge of infrared kite aerial photography: a digital update. Transactions of the Kansas Academy of Science 112(1, 2): 31-39.

Agarwal R.P., Mitra D.S., 1991. Paleogeographic reconstruction of Bengal Delta during Quaternary period. Memoirs - Geological Society of India 22: 13-24.

Birch G.P., 1990. Engineering geomorphological mapping for cliff stability. In: J.B. Burland (ed.) Institute of Civil Engineers (ICE), Chalk: Proceedings of the International Chalk Symposium. Thomas Telford for ICE, London: 545-549.

Butler D.R., 1994. Repeat photography as a tool for emphasizing movement in physical geography. Journal of Geography 93: 141-151. http://dx.doi.org/10.1080/00221349408979710

Cerney D.L., 2010. The use of repeat photography in contemporary geomorphic studies: an evolving approach to understanding landscape change. Geography Compass 4: 1339-1357. http://dx.doi.org/10.1111/j.1749-8198.2010.00376.x

Chandler J., 1999. Effective application of automated digital photogrammetry for geomorphological research. Earth Surface Processes and Landforms 24: 51-63, DOI: 10.1002/(SICI)1096-9837 (199901)24:1<51::AID-ESP948>3.0.CO;2-H.

Erol O., 1999. A geomorphological study of the Sultansazligi lake, central Anatolia. Quaternary Science Reviews 18(4-5): 647-657. http://dx.doi.org/10.1016/S0277-3791(98)00102-4

Foster N.H., Beaumont E.A. (eds.), 1992. Photogeology and photogeomorphology. American Association of Petroleum Geologists, London: $555 \mathrm{pp}$.

Geological Survey of India, 1982. Proceedings of the workshop on problems of the deserts in India, Jaipur: 405 pp.

Hall F.C., 2001. Ground-based photographic monitoring. General Technical Reports of the US Department of Agriculture, Forest Service: $75 \mathrm{pp}$.

Hall F., 2007. Photomonitoring. In: General Technical Report PNW 726, Proceedings of the International Conference on Transfer of Forest Science Knowledge and Technology: 93-101.

Inkpen R., Duane B., Burdett J., Yates T., 2008. Assessing stone degradation using an integrated database and geographical information system (GIS). Environmental Geology 56(3-4): 789-801. http://dx.doi.org/10.1007/s00254-008-1309-x

Inkpen R.J., Fontana D., Collier P., 2001. Mapping decay: integrating scales of weathering within a GIS. Earth Surface Processes and Landforms 26(8): 885-900. http://dx.doi.org/10.1002/esp.234

Kellerhals R., Church M., Bray D.I., 1976. Classification and analysis of river processes. Journal of the Hydraulics Division 102: 813-829.

Kelly T.E., 1961. Photogeology - quick, economical tool for oil hunters. Oil and Gas Journal 59(47): 265-266.

Lind A.O., 1974. Photo-geomorphology of coastal landforms, Cat Island, Bahamas. Army Engineer Topographic Labs, Belvoir: 48 pp.

McKendrick J.H., Bowden A., 1999. Something for everyone? An evaluation of the use of audio-visual resources in geographical learning in the UK. Journal of Geography in Higher Education 23(1): 9-19. http://dx.doi.org/10.1080/03098269985579

McKendrick J.H., Bowden A., 2000. Equipped for the 21st century?: audio-visual resource standards and product demands from geography departments in the UK. Journal of Geography in Higher Education 24(1): 53-73

http://dx.doi.org/10.1080/03098260085135

Miller V.C., 1968. Aerial photographs and surface features - 1. Aerial photographs and land forms (photogeomorphology). In: Aerial surveys and integrated studies: proceedings of the Toulouse Conference. UNESCO, Paris: 41-69.

Mollard J.D., 1973. Landforms and surface materials of Canada: a stereoscopic airphoto altas and glossary. Airphoto Interpretation, Regina: 383 pp.
Mollard J.D., Janes J.R., 1984. Airphoto interpretation and the Canadian landscape. Canadian Government Publishing Centre, Hull: 415 pp.

Mottershead D.N., Bailey B., Collier P., Inkpen R.J., 2003. Identification and quantification of weathering by plant roots. Building and Environment 38: 1235-1241.

http://dx.doi.org/10.1016/S0360-1323(03)00080-5

Niyogi D., 1988. Photogeomorphic and photopedologic mapping of Quaternary formations around Kalna Town, Dist. Barddhaman, W. Bengal. Indian Journal of Earth Sciences 15(3): 216-227.

Oakeshott W.F., 1975. Oxford stone restored: the work of the Oxford Historic Buildings Fund, 1957-1974. Oxford University Press, Oxford: $122 \mathrm{pp}$

Rivard L.A., 2011. Satellite geology and photogeomorphology: an instructional manual for data integration. Springer, Saint-Lambert: 270 pp.

Searle D.E., 2001. The comparative effects of diesel and coal particulate matter on the deterioration of Hollington sandstone and Portland limestone. Ph.D. thesis, University of Wolverhampton.

Sidaway J.D., 2002. Photography as geographical fieldwork. Journal of Geography in Higher Education 26(1): 95-103, DOI: 10.1080/ 03098260120110395

Swallow P., Dallas R., Jackson S., Watt D., 2004. Measurement and recording of historic buildings. Donhead Publishing, Shaftesbury: 224 pp.

Talukdar S.N., 1980. Application of remote sensing techniques to petroleum exploration in India. In: Proceedings Workshop 22nd Plenary Meeting of COSPAR. Pergamon Press, Bangalore: 121-126.

Tator B.A., 1960. Photo interpretation in geology. In: R.N. Colwell (ed.), Manual of photographic interpretation. American Society of Photogrammetry, Falls Church: 169-342.

Thornbush M., 2008a. Grayscale calibration of outdoor photographic surveys of historical stone walls in Oxford, England. Color Research and Application 33(1): 61-67. http://dx.doi.org/10.1002/col.20374

Thornbush M., 2008b. Postcards used to track environmental history. Environmental History 13(2): 360-365. http://dx.doi.org/10.1093/envhis/13.2.360

Thornbush M.J., 2010a. Measurements of soiling and colour change using outdoor rephotography and image processing in Adobe Photoshop along the southern façade of the Ashmolean Museum, Oxford. In: B.J. Smith, M. Gomez-Heras, H.A. Viles, J. Cassar (eds.), Limestone in the built environment: present-day challenges for the preservation of the past. Geological Society, London, Special Publications 331: 231-236. http://dx.doi.org/10.1144/SP331.21

Thornbush M.J., 2010b. Photographic surveys of building exteriors in central Oxford, UK. International Journal of Architectural Heritage 4(4): 351-369. http://dx.doi.org/10.1080/15583050903131355

Thornbush M.J., 2012a. Archaeogeomorphology as an application in physical geography. Applied Geography 34: 325-330. http://dx.doi.org/10.1016/j.apgeog.2011.12.005

Thornbush M.J., 2012b. Tracking the use of climbing plants in the urban landscape through the photoarchives of two Oxford colleges, 18611964. Landscape Research: 1-17.

Thornbush M.J., in press. Digital photography used to quantify the greening of north-facing walls along Broad Street in central Oxford, UK. Géomorphologie: Relief, Processus, Environnement, Special Issue.

Thornbush M.J., Viles H.A., 2004a. Integrated digital photography and image processing for the quantification of colouration on soiled surfaces in Oxford, England. Journal of Cultural Heritage 5(3): 285-290. http://dx.doi.org/10.1016/j.culher.2003.10.004

Thornbush M.J., Viles H.A., 2004b. Surface soiling pattern detected by integrated digital photography and image processing of exposed limestone in Oxford, England. In: C. Saiz-Jimenez (ed.), Air pollution and cultural heritage. A.A. Balkema Publishers, London: 221-224.

Thornbush M., Viles H., 2005. The changing façade of Magdalen College, Oxford: Reconstructing long-term soiling patterns from archival photographs and traffic records. Journal of Architectural Conservation 11(2): 40-57. 
Thornbush M., Viles H., 2006. Changing patterns of soiling and microbial growth on building stone in Oxford, England after implementation of a major traffic scheme. Science of the Total Environment 367(1): 203-211.

http://dx.doi.org/10.1016/j.scitotenv.2005.11.022

Thornbush M.J., Viles H.A., 2007a. Photo-based decay mapping of replaced stone blocks on the boundary wall of Worcester College, Oxford. In: R. Přikryl, B.J. Smith (eds.), Building stone decay: from diagnosis to conservation. Geological Society, London, Special Publications, 271: 69-75.

Thornbush M.J., Viles H.A., 2007b. Simulation of the dissolution of weathered versus unweathered limestone in carbonic acid solutions of varying strength. Earth Surface Processes and Landforms 32(6): $841-852$.

http://dx.doi.org/10.1002/esp.1441
Thornbush M.J., Viles H.A., 2008. Photographic monitoring of soiling and decay of roadside walls in Oxford, England. Environmental Geology 56(3-4): 777-787.

http://dx.doi.org/10.1007/s00254-008-1311-3

Viles H.A., 1993. The environmental sensitivity of blistering of limestone walls in Oxford, England: a preliminary study. In: D.S.G. Thomas, R.J. Allison (eds.), Landscape sensitivity. John Wiley \& Sons Ltd., Chichester: 308-326.

Viles H.A., 1994. Time and grime: studies in the history of building stone decay in Oxford. University of Oxford, Oxford, Research Paper 50

Webb R.H., 1996. Grand Canyon, a century of change: rephotography of the 1889-1890 Stanton Expedition. The University of Arizona Press, Tuscon: $290 \mathrm{pp}$. 